\title{
Efeitos do Banana streak virus no desenvolvimento de cultivares de bananeira
}

\author{
Daniela Garcia Silveira ${ }^{1}$, Tales Miler Soares ${ }^{2}$, Paulo Ernesto Meissner Filho ${ }^{3}$, \\ Francisco Pinheiro Lima Neto ${ }^{4}$, Ranulfo Correa Caldas ${ }^{3}$
}

\begin{abstract}
${ }^{1}$ Doutoranda em Botânica, Universidade Estadual de Feira de Santana (UEFS), Feira de Santana, BA, e-mail:danielags@ig.com.br; ${ }^{2}$ Doutorando da Escola Superior Luis de Quieroz (Esalq), Piracicaba, SP, e-mail: tmsoares@esalq.usp.br; ${ }^{3}$ Embrapa Mandioca e Fruticultura Tropical, CP 7, 44380-000, Cruz das Almas, BA, e-mail: meissner@cnpmf.embrapa.br; ${ }^{4}$ Embrapa Semi-Árido, CP 23, 56300-970, Petrolina, PE, e-mail: fpinheir@cpatsa.embrapa.br. Parte da dissertação de mestrado do primeiro autor.
\end{abstract}

Autor para correspondência: Ranulfo Correa Caldas

Data de chegada: 09/05/2005. Aceito para publicação em: 28/08/2006.

\section{RESUMO}

Silveira, D. G.; Soares, T. M.; Meissner Filho, P. E.; Lima Neto, F. P.; Caldas, R. C. Efeitos do Banana streak virus sobre o desenvolvimento de cultivares de bananeira. Summa Phytopathologica, v.33, n.2, p.190-191, 2007.

Este trabalho avaliou, em condições de casa de vegetação, os efeitos da infecção pelo BSV no crescimento de cinco cultivares de bananeira. Mudas micropropagadas das cultivares SH 3640, FHIA 18, Caipira, Thap Maeo e Pioneira foram inoculadas com BSV pela cochonilha Planacoccus citri Risso. Como controles utilizaram-se mudas não inoculadas e inoculadas com cochonilhas não virulíferas. Avaliou-se a altura das plantas, o diâmetro do pseudocaule, o número de folhas, a área foliar e as massas da matéria seca da parte aérea e da raiz. Os primeiros sintomas do BSV foram detectados 15 dias após a inoculação em todas as plantas inoculadas com o vírus. Houve diferenças estatísticas significativas nas variáveis analisadas, concluindo-se que o vírus afetou o desenvolvimento das plantas de todas as cultivares avaliadas.

Palavras-chave adicionais: BSV, Badnavirus, Planacoccus citri, cochonilha.

\begin{abstract}
Silveira, D. G.; Soares, T. M.; Meissner Filho, P. E.; Lima Neto, F. P.; Caldas, R. C. Effects of banana streak virus on the development of banana cultivars. Summa Phytopathologica, v.33, n.2, p.190-191, 2007.
\end{abstract}

On this study, the BSV effects on five banana cultivars were evaluated under greenhouse conditions. Micropropagated plants of cultivars SH 3640, FHIA 18, Caipira, Thap Maeo and Pioneira were inoculated with BSV using mealybug Planacoccus citri Risso as a vector. Controls plants were inoculated with non-viruliferous mealybugs or not inoculated. Plant height, pseudostem diameter, number of leaves, foliar area and root and shoot dry mass were evaluated. Disease symptoms were first visible 15 days after plant inoculation with virus. Statistical differences were detected for the host growth variables evaluated. It was concluded that BSV affected significantly the growth of all studied cultivars.

Additional keywords: BSV, Badnavirus, Planacoccus citri, mealybug.

A bananeira está sujeita a infecção por vários vírus, entre eles o vírus das estrias da bananeira (Banana streak virus, BSV) que é importante para os programas de melhoramento genético e para a multiplicação de cultivares, uma vez que pode ser incorporado ao genoma das plantas infectadas $(1,3)$. O BSV pertence ao gênero Badnavirus, tem partículas baciliformes não envelopadas (1), contém DNA de fita dupla (5) e produz em bananeiras infectadas um estriado clorótico. As plantas infectadas geralmente não mostram sintomas em todas as folhas (3), apresentam redução do vigor e a diminuição do tamanho dos frutos, que ficam deformados (5).

Este trabalho teve como objetivo avaliar a suscetibilidade de cultivares ao BSV e os efeitos do vírus no seu desenvolvimento.

O trabalho foi conduzido em casa de vegetação sem controle de temperatura, na Embrapa Mandioca e Fruticultura Tropical em Cruz das Almas, BA. Utilizaram-se plantas micropropagadas de bananeira das cultivares SH3640 (AAAB), FHIA-18 (AAAB), Caipira (AAA),
Thap Maeo (AAB) e Pioneira (AAAB), medindo $12 \mathrm{~cm}$ de altura, em média, após 30 a 45 dias de aclimatação. Foram usadas 45 plantas de cada cultivar, divididas em três lotes contendo 15 plantas: o primeiro lote foi inoculado com BSV proveniente de 'Mysore', utilizando-se a cochonilha vetora $P$. citri Risso, o segundo não foi inoculado (TA = testemunha absoluta) e o terceiro foi infestado com cochonilhas não virulíferas $(\mathrm{TR}=$ testemunha relativa $)$. A cochonilha vetora foi utilizada conforme procedimento proposto por $\mathrm{Su}$ (7), com as modificações adotadas por Soares et al. (6), que são descritas a seguir. As cochonilhas foram multiplicadas e mantidas em frutos de abóbora. Em seguida, transferiu-se com auxílio de um pincel 20-30 ínstares jovens do inseto para placas de Petri contendo pedaços de folhas de bananeira 'Mysore', infectada com BSV. Ali as cochonilhas permaneceram durante 24 horas para a aquisição do vírus. Transferiram-se as cochonilhas para as plantas-testes, aderindo-se os pedaços de folha utilizados no acesso de aquisição. Após 48 horas de acesso de transmissão, as cochonilhas 
Tabela 1. Médias da área foliar $\left(\mathrm{cm}^{2}\right.$.folha $\left.{ }^{-1}\right)$, do peso da matéria seca da parte aérea e das raízes $(\mathrm{g})$ de cinco cultivares de bananeira medidas em plantas após 123 dias de cultivo em casa de vegetação.

\begin{tabular}{|c|c|c|c|c|c|c|c|c|c|}
\hline \multirow[b]{2}{*}{ Cultivares } & \multicolumn{3}{|c|}{ Área foliar $\left(\mathrm{cm}^{2}\right.$. folha $\left.{ }^{-1}\right)$} & \multicolumn{3}{|c|}{ Peso da matéria seca da parte aérea (g) } & \multicolumn{3}{|c|}{ Peso da matéria seca das raízes (g) } \\
\hline & TA* & TR & BSV & $\mathbf{T A}$ & TR & BSV & $\mathbf{T A}$ & TR & BSV \\
\hline FHIA 18 & $330,29 \mathrm{bA}$ & $348,35 \mathrm{bcA}$ & $172,18 \mathrm{cB}$ & $12,31 \mathrm{bcA}$ & $13,91 \mathrm{abA}$ & $7,05 \quad b B$ & $10,62 \mathrm{aA}$ & $8,03 \mathrm{aA}$ & $4,67 \mathrm{cB}$ \\
\hline Caipira & $314,78 \mathrm{bB}$ & $365,03 \mathrm{aB}$ & $273,16 \mathrm{bB}$ & $11,20 \quad \mathrm{cA}$ & 11,68 bA & $9,78 \mathrm{aB}$ & $10,33 \mathrm{aA}$ & $8,42 \mathrm{aA}$ & $10,02 \mathrm{aA}$ \\
\hline Thap Maeo & $454,98 \mathrm{aA}$ & $466,69 \mathrm{aA}$ & $334,53 \mathrm{aB}$ & 15,58 aA & 14,51 aA & $10,67 \mathrm{aB}$ & $8,25 \mathrm{aA}$ & $7,02 \mathrm{aA}$ & $7,81 \mathrm{abA}$ \\
\hline
\end{tabular}

*TA = testemunha absoluta, plantas sadias, TR = testemunha relativa, plantas infestadas com cochonilhas não virulíferas e BSV: Plantas infestadas com cochonilhas virulíferas para BSV.

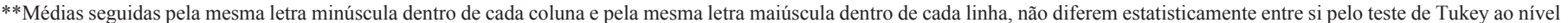
de $5 \%$ de probabilidade.

foram mortas com inseticida. Utilizou-se o delineamento experimental inteiramente casualizado em arranjo fatorial $5 \times 3$ com 15 repetições. Aos 123 dias de instalação do experimento, avaliou-se a altura das plantas, o diâmetro médio do pseudocaule, a cinco centímetros do coleto, com o uso de um paquímetro, o número médio de folhas, a área foliar média das folhas, obtida com um planímetro, e a média da matéria seca da parte aérea e do sistema radicular.

Os sintomas da infecção pelo BSV foram visíveis 15 dias após a inoculação, sendo que $100 \%$ das plantas inoculadas apresentaram sintomas. Esses resultados foram semelhantes aos obtidos por Soares et al. (6) quando inocularam plantas da cultivar 'Caipira' com o BSV. Nesta ocasião plantas de Mysore com sintomas de BSV e de Caipira micropropagadas foram avaliadas por PCR verificando-se que a Mysore utilizada nos experimentos estava infectada pelo BSV e as mudas de Caipira apresentavam-se sadias. Os sintomas permaneceram visíveis nas plantas inoculadas durante toda a fase experimental sendo semelhantes aos relatados por Soares et al. (6) ao inocularem mudas de bananeira com BSV pela cochonilha vetora. Ramirez \& Rivera (5) observaram os mesmos sintomas em plantas de bananeira infectadas com BSV e mantidas em campo.

Aos 123 dias após a infestação com cochonilhas, observou-se que a altura média das plantas infestadas com cochonilhas virulíferas era menor do que a apresentada pelas testemunhas (dados não mostrados). Não se observou diferenças significativas quanto ao diâmetro do pseudocaule e o número de folhas entre as cultivares e os tipos de infestação testados (dados não mostrados). Para as variáveis área foliar e peso da matéria seca da parte aérea, as plantas infestadas com cochonilhas virulíferas apresentaram médias menores do que as plantas sadias e as infestadas com cochonilhas não virulíferas, com exceção da 'Caipira' em relação a área foliar. O BSV não influenciou significativamente o peso da matéria seca das raízes, exceto na 'FHIA 18' (Tabela 1).
Muitos dos sintomas causados por vírus sugerem alterações nos níveis ou no metabolismo dos reguladores de crescimento, ocorrendo à redução do seu porte (nanismo), assim como alterações nas folhas (clareamento das nervuras, mosqueado), (2). Também pode ocorrer redução pigmentos foliares, no tamanho das folhas, flores e raízes, encurtamento dos pecíolos e dos entrenós (4).

Todas as cultivares de bananeira avaliadas foram suscetíveis ao $\mathrm{BSV}$, ocorrendo efeitos no crescimento e no desenvolvimento das plantas.

\section{REFERÊNCIAS BIBLIOGRÁFICAS}

1. Daniells, J.; Thomas, J. E.; Smith, M. Seed transmission of banana streak virus confirmed. Infomusa, Montpellier, v. 4, n. 1, p. 7, 1995 .

2. Goodman, R. N; Király, Z.; Wood, K. R. The biochemistry and physiology of plant diseases. Missouri: University of Missouri Press, 1986. 433 p.

3. Lockhart, B. E. L. Purification and serology of a baciliform virus associated with banana streak disease. Phytopathology, Saint Paul, v.76, n.10, p. 995-999, 1986.

4. Matthews, R. E. F. Plant virology. 3 ed. San Diego: Academic Press, 1991. 835 p.

5. Ramirez, P.; Rivera, C. Enfermidades mirales in banana y plátano. In: Reunion De La Associacion Para La Cooperacion En Investigacion De Banano En Caribe Y En America Tropical, 10., 1991, Tabasco. Memorias... San José: CORBANA, 1994. p. 223230 .

6. Soares, T. M.; Meissner Filho, P. E.; Rocha, H. S. Efeitos do vírus das estrias da bananeira na cultivar Caipira (AAA). In: Congresso Brasileiro de Fruticultura, 16., 2000, Fortaleza. Actas. Fortaleza: Sociedade Brasileira de Fruticultura, 2000. 1 CD-ROM.

7. Su, H. J. First occurrence of banana streak badnavirus and studies on its vectorship in Taiwan. In: Workshop of the PROMUSA Virology Working Group, 1998, Montpellier. Proceedings. Montpellier: INIBAP, 1998, p. 19-25. 